\title{
Protoplasmic Incompatibility in Podospora anserina: Possible Involvement of the Plasma Membrane in the Trigger Mechanism
}

\author{
By DANIEL ASSELINEAU, JEAN BERNET AND \\ JACQUES LABARÈRE* \\ Laboratoire de Génétique, Université de Bordeaux II, allée des Facultés, 33405 Talence, \\ France
}

(Received 20 May 1980; revised 18 December 1980)

\begin{abstract}
Two mutations in the modC locus of Podospora anserina, which abolish the process of cell lysis resulting from the combination of the $R$ and $V$ non-allelic incompatibility genes, have previously been shown to produce complete suppression of a laccase exoenzyme. In the present study it was found that, in addition, the $\bmod C$ mutants show a marked increase in the activity of an amino-acid oxidase (an exo- and endoenzyme), most of the increase (some 9- or 15 -fold) being in the extracellular fraction. The $\bmod C$ mutant strains are hypersensitive to cycloheximide in vivo, but biochemical and genetical investigations suggested that the hypersensitivity is not due to effects on the ribosome. The $\bmod C(1)$ strain also shows increased resistance to chlorate, a specific sensitivity to acid $(6 \cdot 5)$ and neutral $(7 \cdot 5) \mathrm{pH}$, and significant hypersensitivity to methylammonium and thiourea. ModC cells accumulate a higher amount of the urea analogue $\left[{ }^{14} \mathrm{C}\right]$ thiourea. The $\mathrm{pH}$ sensitivity associated with the $\bmod C(1)$ mutation is specifically suppressed by the combination of the $R$ and $V$ incompatibility genes, and the $R V \bmod C(1)$ strain is resistant to sorbose. The specific consequences of the modC(1) mutation and the suppression of some of its effects by the combination of the $R$ and $V$ incompatibility genes lead to the suggestion that protoplasmic incompatibility might be induced by action of the $R / V$ initiating complex in association with the plasma membrane.
\end{abstract}

\section{INTRODUCTION}

In Podospora anserina, protoplasmic incompatibility is a phenomenon of cell destruction resulting from the association of allelic or non-allelic genes (Rizet \& Esser, 1953; Bernet, 1967). Non-allelic incompatibility systems $(C / D, R / V)$ involve the genes of nine loci $(c, d, r$, $v$, etc.). Biochemical investigations have shown that protoplasmic incompatibility essentially consists of either a marked increase in or de novo synthesis of specific enzymes, especially a proteolytic enzyme suspected of being responsible for cell lysis (Bégueret \& Bernet, 1973; Boucherie et al., 1976).

From the study of mutations of incompatibility genes (Bernet \& Belcour, 1967; Bernet \& Bégueret, 1967), it was suggested that incompatibility genes might be the structural genes for protein factors whose specific interaction was the basic mechanism initiating protoplasmic incompatibility. Micrurgical studies involving hyphal anastomoses between strains of different genotypes (Bernet, 1965; Labarère et al., 1974) revealed that in each pair of interacting non-allelic factors one participant was in the form of a soluble cytoplasmic factor showing extensive diffusion in hyphae. Further investigations gave no information as to the location of the non-diffusible factor or on the subcellular component supporting the non-allelic interactions. 
Mutations in the $\bmod A$ gene abolished cell lysis irrespective of the non-allelic system $(C / D$, $R / V$ ) involved in protoplasmic incompatibility. Indirect evidence, namely the sensitivity of the $\bmod A$ gene product to dihydrostreptomycin and its inhibitory action on translation, suggested that $\bmod A$ was a ribosomal gene and consequently that the ribosomes might be the site of non-allelic incompatibility gene interaction (Bernet et al., 1973; Labarère et al., 1974). However, no direct evidence in support of the idea that the modA gene product was really a ribosomal factor was obtained.

Mutations in the modC gene have been selected on the basis of the suppression of protoplasmic incompatibility resulting from the combination of the $R$ and $V$ non-allelic incompatibility genes (Labarère \& Bernet, 1977). The results of the present study show that collateral resistances or hypersensitivities to various unrelated drugs are associated with the $\bmod C$ mutation. They suggest that the $\bmod C$ gene product might be an intrinsic constituent of the plasma membrane.

\section{METHODS}

Organism. Podospora anserina is a heterothallic ascomycete whose life cycle closely resembles that of Neurospora crassa. Its asci contain four binucleate spores that include the two products of a half tetrad. In about $5 \%$ of asci, one binucleate spore is replaced by two uninucleate spores. These give rise to the homokaryotic strains used in our experiments. For details see Esser (1974).

The $r$ and $v$ incompatibility loci. The original isolates of geographical races of $P$. anserina were $r V$ or $R V 1$ (Bernet, 1967). In these strains the $R / V$ non-allelic incompatibility system is present in addition to the $V / V I$ allelic system. The $ᄋ r V \times \delta R V I$ cross was the source of the $R V$ lethal strain which combines the $R$ and $V$ incompatibility genes. In the $R V$ strain growth stops soon after spore germination and the cells lyse in response to the $R / V$ interaction (Bernet, 1965).

Strains and mutations. The $r V$ genotype was the standard genetic background of strains. Mutations in the $\bmod C$ gene- $\bmod C(1)$ and $\bmod C(2)$ - were selected on the basis of the suppression of the process of cell destruction resulting from the union of the $R$ and $V$ incompatibility genes (Labarère \& Bernet, 1977). The mutations $c y R 1$ and $c y R 2$ were non-allelic ribosomal mutations selected for the ability to confer resistance to cycloheximide (Crouzet, 1978; Crouzet \& Bégueret, 1978).

Amino-acid oxidase assay. Cell-free extracts from cultures grown on synthetic medium were prepared according to the procedure of Boucherie et al. (1976). The assay for amino-acid oxidase activity was that described by Rahe et al. (1970) for phenylalanine ammonia-lyase as modified by Boucherie \& Bernet (1978). The reaction mixture contained $0.85 \mathrm{ml} 0.1 \mathrm{M}$-borate buffer $\mathrm{pH} 8 \cdot 8,0.5 \mu \mathrm{Ci} \mathrm{L}-\left[\mathrm{U}-{ }^{14} \mathrm{C}\right.$ ]phenylalanine (specific activity $436 \mathrm{mCi} \mathrm{mmol}^{-1}$; $1 \mathrm{Ci}=37 \mathrm{GBq})$ in $0.05 \mathrm{ml}$ buffer and $1 \mathrm{ml}$ dialysed supernatant $\left(1 \mathrm{mg}\right.$ protein $\left.\mathrm{ml}^{-1}\right)$. After incubation at $37^{\circ} \mathrm{C}$ for $10 \mathrm{~min}$ the reaction was stopped by adding $0.16 \mathrm{ml} 12 \mathrm{M}-\mathrm{HCl}$. For controls, the reaction was stopped at zero time. After centrifugation of the mixture at $10000 \mathrm{~g}$ for $10 \mathrm{~min}$ the supernatant was collected and phenylpyruvate was extracted as an enol-borate complex with $2 \mathrm{ml}$ diethyl ether. The radioactivity of the ether fraction was determined by liquid scintillation spectroscopy.

Thiourea uptake. Mycelium was grown in a synthetic alkaline $(\mathrm{pH} 8.5)$ liquid medium in Roux bottles for $12 \mathrm{~h}$ at $26^{\circ} \mathrm{C}$, and $1 \mathrm{ml}$ fractions of the culture were then incubated with $10 \mu \mathrm{Ci}\left[{ }^{14} \mathrm{C}\right]$ thiourea (specific activity $\left.2 \mathrm{mCi} \mathrm{mmol}^{-1}\right)$. At appropriate intervals thiourea uptake was stopped by the addition of $1 \mathrm{ml}$ ice-cold non-radioactive thiourea solution $\left(1 \mathrm{mg} \mathrm{ml}^{-1}\right)$. The mycelium was collected on Whatman GF/C filters by suction and washed three times with $5 \mathrm{ml}$ of the same arrest solution. The filters were transferred into $5 \mathrm{ml} \mathrm{NCS}$ scintillation fluid for radioactivity counting. For reference, the uptake and incorporation of a ${ }^{14} \mathrm{C}$-labelled amino acid mixture (specific activity $50 \mathrm{mCi} \mathrm{mmol}^{-1}$ of each amino acid) was measured. The amount of label incorporated into proteins was determined by boiling each sample for $15 \mathrm{~min}$ with an equal volume of $10 \%(\mathrm{w} / \mathrm{v})$ trichloroacetic acid (TCA), and collecting the precipitate on Whatman GF/C filters. Filters were rinsed three times with $5 \mathrm{ml} 5 \%$ TCA and transferred to $5 \mathrm{ml}$ NCS scintillation fluid for radioactivity counting. The $\left[{ }^{14} \mathrm{C}\right]$ thiourea and the ${ }^{14} \mathrm{C}$-labelled amino acid mixture were provided by CEA, Saclay, France.

Preparation of ribosomes and poly $(U)$-directed polyphenylalanine synthesis. Preparation of ribosomes and in vitro polypeptide synthesis were carried out according to Crouzet et al. (1978). For in vitro polypeptide synthesis, the reaction mixture (total volume $125 \mu$ ) contained $25 \mu$ dialysed $\mathrm{S} 140,50 \mathrm{mM}-\mathrm{Tris} / \mathrm{HCl}, \mathrm{pH} 7.8$. $10 \mathrm{~mm}$-magnesium acetate, $25 \mathrm{mM}-\mathrm{KCl}, 16 \mathrm{~mm}-2$-mercaptoethanol, $6 \mathrm{mM}$-phosphoenolpyruvate, $2 \mathrm{~mm}$-ATP, $0.5 \mathrm{mM}$-GTP, $150 \mu \mathrm{g}$ yeast tRNA, 3 units of pyruvate kinase, $20 \mu \mathrm{g}$ poly $(\mathrm{U}), 0.125 \mu \mathrm{Ci}\left[{ }^{14} \mathrm{C}\right.$ ]phenylalanine $(450$ $\mathrm{mCi} \mathrm{mmol}{ }^{-1}$ ) and $2.5 A_{260}$ units of ribosomes. After incubation at $37^{\circ} \mathrm{C}$ for $30 \mathrm{~min}, 125 \mu 10 \%$ TCA was added 
and the tubes were heated for $15 \mathrm{~min}$ at $90^{\circ} \mathrm{C}$. After cooling, the precipitates were collected on Whatman GF/C filters. The filters were rinsed with $5 \%$ TCA and the radioactivity was assayed.

Preparation of polysomes and assay of their activity in vitro. This was done as described by Crouzet \& Bégueret (1980).

\section{RESULTS}

\section{Overproduction of amino-acid oxidase activity by the modC mutants}

In wild-type strains, some amino-acid oxidase is found in cell extracts but the major part of the overall activity is associated with an exoenzyme (Boucherie \& Bernet, 1978). In modC(1) and $\bmod C(2)$ strains the amino-acid oxidase activity in the culture medium was, respectively, 15 times and 9 times greater than that in the wild-type; by contrast, in the cell extracts the activity was only 1.2 times greater.

\section{Sensitivity of modC strains to cycloheximide}

In vivo resistance or hypersensitivity to cycloheximide generally provides a good indication of the presence of mutations affecting the ribosomes in eukaryotes (Pestka, 1971; Pongratz \& Klingmüller, 1973; Rothschild et al., 1975). Resistance to cycloheximide may be associated with different ribosomal proteins (Bégueret et al., 1977; Crouzet et al., 1978; Cooper et al., 1967; Haugli \& Dove, 1972). Furthermore, ribosomal mutations selected on a basis other than cycloheximide resistance were associated with in vivo and in vitro resistance or hypersensitivity to cycloheximide (Bayliss \& Vinopal, 1971; Coppin-Raynal, 1977).

The results in Fig. 1 show that the modC(1) strain was hypersensitive to cycloheximide in vivo. This hypersensitivity was indicated by a significant increase of the initial lag time before growth renewal after inoculation, and by an approximately $40 \%$ reduction in growth yield (mycelial diameter). The $\bmod C(2)$ strain showed a lower sensitivity: the lag period was only $2 \mathrm{~d}$ and the reduction in growth yield was only $30 \%$.

$C y R 1$ and $c y R 2$ are mutations to cycloheximide resistance which alter two different proteins of the $60 \mathrm{~S}$ subunit (Crouzet, 1978). None of the double mutants combining modC(1) or $\bmod C(2)$ with one of the $c y R$ mutations showed a phenotypic trait, such as cold or heat sensitivity, which would suggest functional interdependence between the $\bmod C$ and $c y R$ loci. Furthermore, the $\bmod C c y R 1 c y R 2$ triple mutant showed no significant difference from the $c y R 1$ cyR 2 double mutant which is cold sensitive (Crouzet \& Bégueret, 1978). Similar negative results were also obtained from studies of in vivo resistance to cycloheximide of the $\bmod C c y R$ double mutants. In particular, the presence of the $\bmod C(1)$ mutation reduced to the same extent $(40 \%)$ the cycloheximide resistance conferred by the $c y R 1$ or by the $c y R 2$ mutation (Fig. 2). Thus, all these results failed to support the idea that the modC mutations might affect the ribosomes.

In vitro studies were thus the only means of determining whether or not $\bmod C$ sensitivity to cycloheximide in vivo was ribosomal. For each $\bmod C$ mutation $[\bmod C(1)$ and $\bmod C(2)]$ the following three $\operatorname{modC} / \bmod C^{+}$genotype pairings were considered: $\bmod C /$ wild-type, $\bmod C \operatorname{cyR} 1 / \operatorname{cyR} 1$ and $\bmod C \operatorname{cyR} 2 / \operatorname{cyR} 2$. Polysomes and ribosomes were extracted from strains of these nine genotypes. The effect of cycloheximide concentrations ranging from 5 to $200 \mu \mathrm{g} \mathrm{ml}^{-1}$ on the elongation activity of the polysomes and on phenylalanine incorporation in ribosome preparations was determined. No difference was observed between two strains belonging to the same genotype pairing.

Hence, it is possible that the in vivo hypersensitivity to cycloheximide of the modC strains is the consequence of an increased permeability of the modC cells to the antibiotic. If modC strains were in fact affected in the cell envelopes it might be expected that they would also show hypersensitivity or increased resistance to various toxic drugs. 


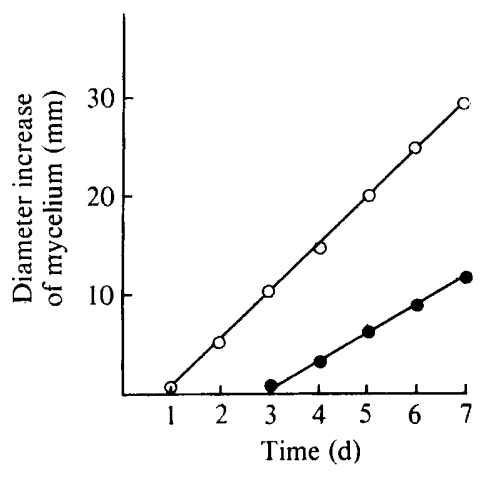

Fig. 1

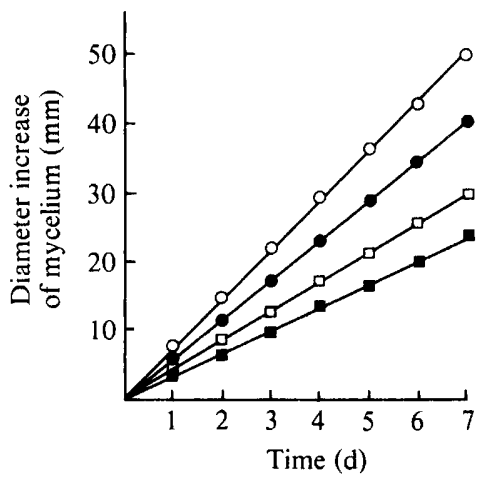

Fig. 2

Fig. 1. Effect of cycloheximide $\left(2.5 \mu \mathrm{g} \mathrm{ml}^{-1}\right)$ on growth of $\bmod C(1)(\mathrm{O})$ and wild-type (O) strains. Inocula were placed on the surface of the culture medium at zero time.

Fig. 2. Effect of cycloheximide $\left(20 \mu \mathrm{g} \mathrm{ml}^{-1}\right)$ on growth of the cycloheximide-resistant strains $c y R 1(O)$ and $c y R 2(O)$, and the double mutants $\bmod C(1) c y R l(\square)$ and $\bmod C(1) \operatorname{cy} R 2(\square)$.

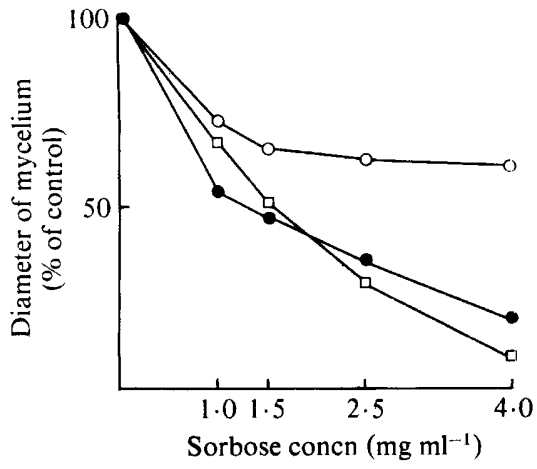

Fig. 3

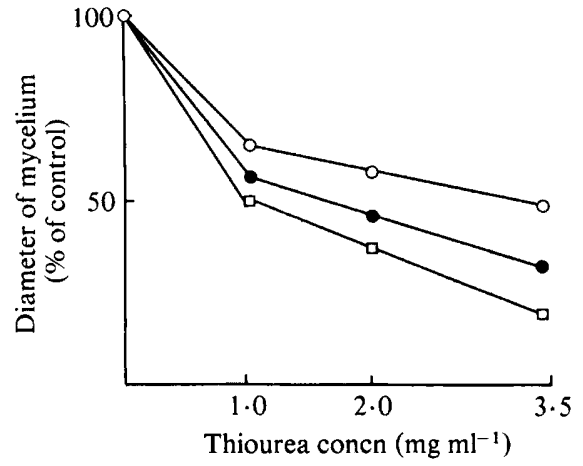

Fig. 4

Fig. 3. Effect of sorbose on growth of $\bmod C(l)(\square), R V \bmod C(l)(O)$ and wild-type (O) strains. The diameters of the mycelia were measured $48 \mathrm{~h}$ after placing the inocula on the surface of the culture medium.

Fig. 4. Effect of thiourea on growth of $\bmod C(l)(\square), \bmod C(2)(O)$ and wild-type $(O)$ strains. The diameters of the mycelia were measured $48 \mathrm{~h}$ after placing the inocula on the surface of the culture medium.

Resistance of the modC strains to L-sorbose and chlorate and their sensitivity to acid and neutral $\mathrm{pH}$ and to methylammonium and thiourea

The following analogues were used: 2-deoxyglucose, L-sorbose, methylammonium, chlorate, thiourea, 5-fluorouracil, $p$-fluorophenylalanine and ethionine. Significant differences between the modC strains and the wild-type were observed in media supplemented with L-sorbose, methylammonium, chlorate or thiourea. In fungi, the presence of L-sorbose in the culture medium results in the formation of slow-growing (colonial) mycelia. It can be seen from Fig. 3 that the modC(1) strain showed some resistance (growth yield 1.2 times that of the wild-type) at a low sorbose concentration $\left(1.0 \mathrm{mg} \mathrm{ml}^{-1}\right)$ and was hypersensitive at concentrations of $2.5 \mathrm{mg} \mathrm{ml}^{-1}$ or more. 


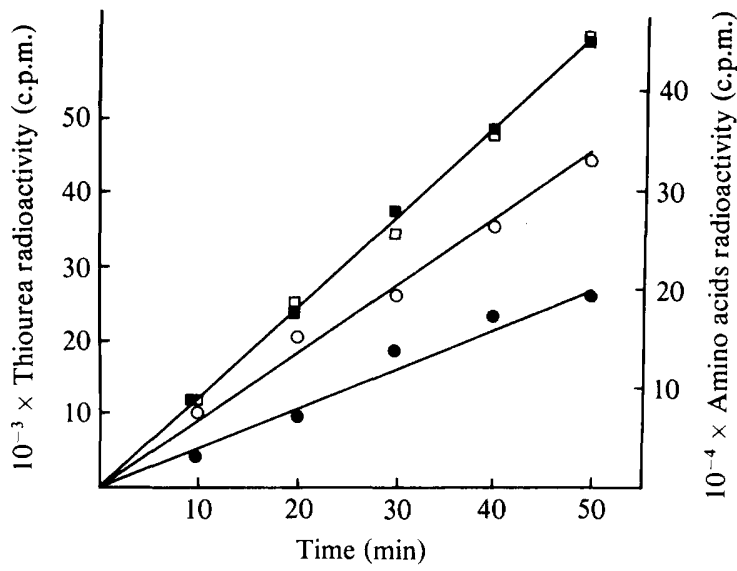

Fig. 5. $\left[{ }^{14} \mathrm{C}\right.$ ]Thiourea uptake by $\bmod C(1)(\mathrm{O})$ and wild-type $(\Theta)$ strains and, as a control to indicate growth, the incorporation of ${ }^{14} \mathrm{C}$-labelled amino acids into protein by $\bmod C(1)(\square)$ and wild-type ( $\square$ ) strains. The strains were grown at $26^{\circ} \mathrm{C}$ in a liquid medium maintained at $\mathrm{pH} 8.5$; in this medium the $\bmod C(1)$ strain grows at the same rate as wild-type.

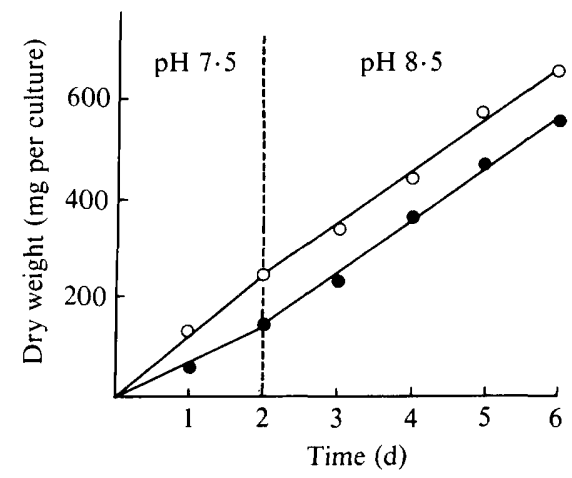

Fig. 6. Effect of $\mathrm{pH}$ on the increase in dry weight of $\bmod C(1)(O)$ and wild-type (O) strains. After $2 \mathrm{~d}$ culture in liquid medium at $26^{\circ} \mathrm{C}$, the $\mathrm{pH}$ of the medium was raised from $7 \cdot 5$ to $8 \cdot 5$.

Methylammonium is an ammonium analogue (Roon et al., 1975). High concentrations of methylammonium were needed to obtain significant inhibition of the growth of $P$. anserina strains. At $20 \mathrm{mg} \mathrm{ml}^{-1}$ the wild-type was completely unaffected: at the same concentration the growth yield of the $\bmod C(1)$ and $\bmod C(2)$ strains was inhibited by more than $40 \%$.

The effect of chlorate on fungal growth is controversial. It has been postulated that it is transformed into a toxic chlorite by nitrate reductase (Aberg, 1947) or has, in addition, a side effect which indirectly results in nitrogen starvation (Cove, 1976). To obtain inhibition of the growth of $P$. anserina the experiments with chlorate had to be conducted in Aspergillus culture medium (Cove, 1976). At a chlorate concentration of $30 \mathrm{mg} \mathrm{m}^{-1}$ wild-type growth was reduced by about $50 \%$, whereas that of the $\bmod C(1)$ strain was completely unaffected.

Thiourea is a urease inhibitor (Dunn \& Patemann, 1972). The two modC strains, especially $\bmod C(1)$, showed a greater sensitivity to thiourea than the wild-type (Fig. 4). The cause of this hypersensitivity was investigated by means of labelled thiourea. The results in Fig. 5 clearly show that the $\bmod C(1)$ strain accumulated more label than the wild-type following the addition of $\left[{ }^{14} \mathrm{C}\right]$ thiourea. Under the conditions used, there was no difference in growth 
between the wild-type and the $\bmod C(1)$ strain, as shown by incorporation into proteins of ${ }^{14} \mathrm{C}$-labelled amino acids.

The $\bmod C(1)$ strain and wild-type were cultured in liquid standard media with the $\mathrm{pH}$ adjusted daily to $6.5,7.5$ or 8.5 . The wild-type showed identical growth (dry weight per culture) at each $\mathrm{pH}$. The modC(1) strain showed practically no growth (less than $5 \%$ of the wild-type yield) at $\mathrm{pH} 6.5$, a growth yield of $70 \%$ of the wild-type at $\mathrm{pH} 7.5$ and the equivalent of wild-type growth at $\mathrm{pH} 8.5$. When the $\mathrm{pH}$ of the medium was increased from 7.5 to 8.5 during the growth of a modC(1) culture, the growth rate showed a marked increase (Fig. 6) indicating that the $\mathrm{pH}$ sensitivity of the modC cultures was not restricted to renewal of growth after inoculation.

\section{Combination of the $R$ and $V$ incompatibility genes}

The strains of $R V \bmod C$ genotypes $[\bmod C(1)$ or $\bmod C(2)]$ were compared with the modC and wild-type strains. The $R V \bmod C$ strains clearly showed four of the properties which distinguish modC from wild-type strains, namely chlorate resistance and hypersensitivity to thiourea, methylammonium and cycloheximide. In contrast, the $R V \bmod C$ strains differed significantly from the $\bmod C$ strains in $\mathrm{pH}$ dependence and from the $\bmod C$ and wild-type strains in sorbose sensitivity. As shown above, the $\bmod C(1)$ strain exhibited wild-type growth only at $\mathrm{pH} 8.5$. The $R V \bmod C(1)$ strain showed the equivalent of wild-type growth at $\mathrm{pH} 7.5$ and $6 \cdot 5$. Hence, it may be concluded that the combination of the $R$ and $V$ incompatibility genes suppresses the sensitivity to acid and neutral $\mathrm{pH}$ associated with the modC(1) mutation. In contrast to the $\bmod C(1)$ strain, the $R V \bmod C(1)$ strain was hyperresistant to sorbose at all concentrations of the sugar tested (Fig. 3).

Besides the $R V$ combination, which is lethal in the absence of modC mutations, three genotypes were possible with the wild-type alleles $r$ and $R, V$ and $V 1$ of the $r$ and $v$ incompatibility loci (Labarère, 1973): $r V, r V 1$ and $R V 1$. The genetic background of the modC strains investigated in the experiments described above was $r V$. Strains of $r V 1$ modC and $R V I$ modC genotypes were constructed. These showed a $\mathrm{pH}$ dependence and a sorbose sensitivity identical to those of the $r V \bmod C$ strains. In consequence, it might be concluded that the suppression of the $\mathrm{pH}$ sensitivity associated with the $\bmod C$ mutation, which was observed in the $R V \bmod C$ strain, was not the result of the presence of the $R$ or $V$ genes but of their combination. In the same way, the sorbose resistance specific to the $R V \bmod C$ genotype is clearly the result of the three-gene combination, since any substitution in one of the three loci $(r, v$ and $\bmod C)$ resulted in strains showing a nearly identical sensitivity to sorbose.

Additional support for this interpretation came from investigation of the $R V \bmod C(1)$ strain at $32{ }^{\circ} \mathrm{C}$. It is known (Labarère, 1973) that the combination of the $R$ and $V$ incompatibility genes which is lethal at $26^{\circ} \mathrm{C}$ (in the absence of the $\bmod C$ mutations) gives a wild-type phenotype at $32^{\circ} \mathrm{C}$. At the latter temperature the $R V \bmod C(1)$ strain showed the same $\mathrm{pH}$ dependence and sorbose resistance as the $\bmod C(1)$ strain that carried genes in the $r$ and $v$ loci whose association did not result in protoplasmic incompatibility.

\section{DISCUSSION}

Since the $\bmod C(1)$ cells incorporated more radioactive label than the wild-type following the addition of $\left[{ }^{14} \mathrm{C}\right]$ thiourea (Fig. 5), it is possible that the modC $(1)$ mutation results in an alteration of the plasma membrane or the cell wall. All the properties associated with the modC mutations (methylammonium sensitivity, chlorate resistance, non-ribosomal cycloheximide sensitivity) support this interpretation. Collateral hypersensitivity or resistance to the effects of unrelated inhibitors have been previously described in a variety of organisms (Eriksson-Greenberg et al., 1971; Ling \& Thompson, 1974; Sanderson et al., 1974; Rank et al., 1975); in all cases a lesion of the cell envelope was demonstrated or strongly suspected. In 
view of the $\mathrm{pH}$ sensitivity of the $\operatorname{modC}(1)$ strain (Fig. 6), it may be inferred that this strain carries a lesion of the plasma membrane.

The modC strains are defective in laccase III activity (Labarère \& Bernet, 1978), an exoenzyme whose synthesis is dependent on stable mRNA (Boucherie, 1979). The present results show that amino-acid oxidase, which also depends on a stable mRNA, was significantly increased in modC cultures, especially in the extracellular region. Mutant strains showing a deregulation of one or several exoenzymes (i.e. suppression, hyperproduction or a strong imbalance in the ratio of intracellular to extracellular enzyme activity) have been reported (Gratzner, 1972; Yoneda et al., 1973; Murayama \& Ishikawa, 1973; Kunst et al., 1974); all these mutants were thought to be altered in their cell envelopes (plasma membrane or cell wall). The properties of $\bmod C$ strains thus suggest that the plasma membrane contains determinants which regulate the production of exoenzymes and, more generally, of proteins depending on stable mRNA.

It was previously postulated that the $\bmod C$ mutations might prevent the formation of a complex between the interacting $R$ and $V$ gene products whose presence is the basic mechanism initiating protoplasmic incompatibility (Labarère \& Bernet, 1977). Suppression of the $\mathrm{pH}$ dependence associated with the $\bmod C(1)$ mutation by the combination of the $R$ and $V$ incompatibility genes and not by any of the other three non-lethal $r v$ combinations (i.e. the $r V$ and $R V I$ wild-type genotypes and the recombinant $r V 1$ ) suggests that the $R / V$ complex is in fact formed in the $R V \bmod C(1)$ strain, but is non-functional because of the presence of the $\bmod C$ mutation. In the same way the sorbose resistance specifically associated with the $R V \bmod C$ strains (Fig. 3) is consistent with the formation of the $R / V$ complex in association with the plasma membrane. The $V$ gene product is in the form of a soluble factor spreading in hyphae whereas that of the $R$ gene is a non-diffusible determinant (Labarère et al., 1974). The present results thus suggest that the $R$ gene product might be associated with the plasma membrane in a way similar to that of the $\bmod C$ gene.

Thanks are due to Mrs M.-L. Penin and M. Sabourin for technical assistance. This research is supported by le Conseil Scientifique de l'Université de Bordeaux II, le Centre National de la Recherche Scientifique (Equipe de Recherche Associée no. 485 et Action Thématique Programmée 'Microbiologie 79'), l'Institut National de la Santé et de la Recherche Médicale and la Fondation pour la Recherche Médicale.

\section{REFER $\Xi N C E S$}

AbERG, B. (1947). On the mechanism of the toxic action of chlorate and some substances upon young wheat plants. Kungliga Lantbrutshögskolans annaler 15, 37-107.

BAYLISS, F. \& VINOPAL, R. (1971). Selection of ribosomal mutants by antibiotic suppression in yeast. Science 174, 319-322.

BÉgueret, J. \& Bernet, J. (1973). Proteolytic enzymes and protoplasmic incompatibility in the fungus Podospora anserina. Nature New Biology 243, 94-96.

Bégueret, J., Perrot, M. \& Crouzet, M. (1977). Ribosomal proteins in the fungus Podospora anserina: evidence for an electrophoretically altered $60 S$ protein in a cycloheximide resistant mutant. Molecular and General Genetics 156, 141-144.

BERNET, J. (1965). Mode d'action des gènes de barrage et relation entre l'incompatibilité cellulaire et l'incompatibilité sexuelle chez le champignon Podospora anserina. Annales des sciences naturelles (Botanique) 6, 611-768.

BERNET, J. (1967). Les systèmes d'incompatibilité chez le champignon Podospora anserina. Compte rendu hebdomadaire des séances de l'Académie des sciences D265, 1536-1539.

Bernet, J. \& BÉgueret, J. (1967). Sur les propriétés et la structure des facteurs cytoplasmiques d'incompatibilité chez le Podospora anserina. Compte rendu hebdomadaire des séances de l'Académie des sciences D266, 716-719.

Bernet, J. \& Belcour, L. (1967). Sur la possibilité de sélectionner des mutants de gènes d'incompatibilité chez le Podospora anserina et sur les propriétés des premiers allèles obtenus. Compte rendu hebdomadaire des séances de l'Académie des sciences D265, 1330-1333.

Bernet, J., BÉgueret, J. \& LABArĖre, J. (1973). Incompatibility in the fungus Podospora anserina: are the mutations abolishing the incompatibility reaction ribosomal mutations? Molecular and General Genetics 124, 35-50.

BOUCHERIE, H. (1979). L'incompatibilité protoplasmique chez le champignon Podospora anserina: caractérisation et régulation des variations physiologiques associées, relation avec la différenciation des organes reproducteurs femelles. Thèse, Université Bordeaux II, France. 
Boucherie, H. \& Bernet, J. (1978). Protoplasmic incompatibility and self-lysis in Podospora anserina: enzymes associated with cell destruction. Canadian Journal of Botany 56, 2171-2176.

Boucherie, H., Bégueret, J. \& Bernet, J. (1976). The molecular mechanism of protoplasmic incompatibility and its relationship to the formation of protoperithecia in Podospora anserina. Journal of General Microbiology 92, 59-66.

CoOper, D., BANThorpe, D. V. \& Wilkie, D. (1967). Modified ribosomes conferring resistance to cycloheximide in mutants of Saccharomyces cerevisiae. Journal of Molecular Biology 26, 347-355.

Coppin-RAYNAL, E. (1977). Ribosomal suppressors and antisuppressors in Podospora anserina: resistance to cycloheximide. Journal of Bacteriology 131, 876-883.

Cove, D. J. (1976). Chlorate toxicity in Aspergillus nidulans. Molecular and General Genetics 146. 147-159.

Crouzet, M. (1978). Etude génétique et biochimique de mutants résistants à la cycloheximide chez le Podospora anserina. Thèse, Úniversité Bordeaux II, France.

Crouzet, M. \& Bégueret, J. (1978). Cold-sensitivity of a double mutant strain combining two ribosomal mutations in the ascomycete Podospora anserina. Molecular and General Genetics 165, 283-288.

Crouzet, M. \& Bégueret, J. (1980). A new mutant form of the ribosomal protein L21 in the fungus Podospora anserina: identification of the structural gene for this protein. Molecular and General Genetics 180, 177-183.

Crouzet, M., Perrot, M., Nogueira, M. \& BÉGuereT, J. (1978). Genetic and biochemical analysis of cycloheximide resistance in the fungus Podospora anserina. Biochemical Genetics 16, 271-285.

DunN, E. \& Pateman, J. A. (1972). Urea and thiourea uptake in Aspergillus nidulans. Heredity 29, 129131.

ERIKSSON-GREENBERG, K. G., NoRdSTRÖM, K. \& ENGLAND, P. (1971). Resistance of Escherichia coli to penicillins. IX. Genetics and physiology of class II ampicillin-resistant mutants that are galactose negative or sensitive to bacteriophage $\mathrm{C} 21$ or both. Journal of Bacteriology 108, 1210-1223.

EsSER, K. (1974). Podospora anserina. In Handbook of Genetics, vol. 1, pp. 531-551. Edited by R. C. King. New York \& London: Plenum Press.

GratzNer, G. (1972). Cell wall alteration associated with the hyperproduction of extracellular enzymes in Neurospora crassa. Journal of Bacteriology 111 , 443-446.

Haugli, F. B. \& Dove, W. F. (1972). Genetics and biochemistry of cycloheximide resistance in Physarum polycephalum. Molecular and General Genetics 118, 97-103.

Kunst, F., Pascal, M., Lepesant-Kejzkarova, J., Lepesant, J. A., Billant, A. \& Dedonder, R. (1974). Pleiotropic mutations affecting sporulation conditions and the synthesis of extracellular enzymes in Bacillus subtilis 168. Biochimie 56, 1481-1489.

LABARÈre, J. (1973). Propriétés d'un système d'incompatibilité chez le champignon Podospora anserina et intérêt de ce système pour l'étude de l'incompatibilité. Compte rendu hebdomadaire des séances de l'Académie des sciences D276, 1301-1304.

LABARÈre, J. \& Bernet, J. (1977). Protoplasmic incompatibility and cell lysis in Podospora anserina: genetic investigations on mutations of a novel modifier gene that suppresses cell destruction. Genetics 87, 249-257.

LABARÈRE, J. \& BERNET, J. (1978). A mutation inhibiting protoplasmic incompatibility in Podospora anserina that suppresses an extracellular laccase and protoperithecium formation. Journal of General Microbiology 109, 187-189.

LABARÉre, J., Bégueret, J. \& Bernet, J. (1974). Incompatibility in Podospora anserina: comparative properties of the antagonistic factors of a nonallelic system. Journal of Bacteriology 120, 854-860.

LiNG, V. \& Thompson, L. (1974). Reduced permeability in CHO cells as a mechanism of resistance to colchicine. Journal of Cellular Physiology 83, 103-116.

Murayama, T. \& Ishikawa, T. (1973). Mutations in Neurospora affecting some of the extracellular enzymes and several growth characteristics. Journal of Bacteriology 115, 798-804.

PestKa, S. (1971). Inhibitors of ribosome functions. Annual Review of Microbiology 25, 487-562.

Pongratz, M. \& Klingmüller, W. (1973). Role of ribosomes in cycloheximide resistance of Neurospora mutants. Molecular and General Genetics 124, 359-367.

Rahe, J. E., Kuc, J. \& Chuang, C. M. (1970). Cinnamic acid production as a method of assay for phenylalanine ammonia-lyase in acetone powders of Phaseolus vulgaris. Phytochemistry 9, 10091015.

RANK, G. H., Robertson, A. \& Philipps, K. (1975). Reduced plasma membrane permeability in a multiple cross-resistant strain of Saccharomyces cerevisiae. Journal of Bacteriology 122, 359365.

RIzET, G. \& EssER, K. (1953). Sur les phénomènes d'incompatibilité entre les souches d'origines différentes chez Podospora anserina. Compte rendu hebdomadaire des séances de l'Académie des sciences D237, 760-762.

RoON, R. J., Even, H. L., DuNLOP, P. \& LaRIMORE, F. L. (1975). Methylamine and ammonia transport in Saccharomyces cerevisiae. Journal of Bacteriology 122, 502-509.

Rothschild, H., Germershausen, J. \& Suskind, S. R. (1975). Biochemical and genetic studies of cycloheximide resistance in Neurospora crassa. Biochemical Genetics 13, 283-290.

SANDERson, K. E., MACAlister, T. \& Costerton, J. W. (1974). Permeability of lipopolysaccharidedeficient (rough) mutants of Salmonella typhimurium to antibiotics, lysozyme and other agents. Canadian Journal of Microbiology 20, 11351145.

Yoneda, Y., Yamane, K. \& Maruo, B. (1973). Membrane mutation related to the production of extracellular $\alpha$-amylase and protease in Bacillus subtilis. Biochemical and Biophysical Research Communications 50, 765-771. 